\title{
Microbial Load and the Prevalence of Escherichia coli, Salmonella spp. and Listeria spp. in Ready-to-Eat Products in Trinidad
}

\author{
A. Hosein, K. Muñoz, K. Sawh, and A. Adesiyun* \\ School of Veterinary Medicine, Faculty of Medical Sciences, University of the West Indies, St. Augustine, Trinidad and \\ Tobago, West Indies
}

\begin{abstract}
This study was designed to determine the prevalence and microbial load of Listeria spp., Escherichia coli O157 and Salmonella spp. in ready-to-eat products in supermarkets across Trinidad. The microbial load was assessed using the total aerobic plate count (TAPC) per $\mathrm{g} / \mathrm{ml}$ of foods and prevalence of Escherichia coli $\mathrm{O} 157$ and Salmonella spp. determined using conventional methods. For Listeria monocytogenes, immunomagnetic separation (IMS), TECRA (enzymelinked immunosorbent assay, ELISA) and conventional methods were used. The $\log _{10}$ mean \pm sd TAPC per $\mathrm{g}$ or ml was highest for vegetables $(11.0 \pm 11.6)$, and lowest for seafood $(5.2 \pm 5.7)(\mathrm{p}<0.05)$. The prevalence of L. monocytogenes was $1.7 \%$. Sixteen (4.5\%) of 153 samples yielded E. coli but all samples were negative for Salmonella spp. and E. coli O157. The high microbial load and isolation of L. monocytogenes and E. coli from popular RTE foods could pose a health risk to consumers in the country.
\end{abstract}

\section{INTRODUCTION}

Ready-to-eat (RTE) foods pose a health threat to consumers, since any microorganisms present will be consumed as compared to food that is cooked before eating which should kill most of the microorganisms. These foods are usually refrigerated until consumed, which would normally inhibit the growth of bacteria, but Listeria monocytogenes will continue to grow at this temperature (Huss et al. 2000) [1].

The microbial load and the presence of the bacterial pathogens in foods are a good indication of the food quality and the potential health risk they pose to consumers (Rosmini et al. 2002) [2].

Listeria monocytogenes, Escherichia coli $0157: \mathrm{H} 7$ and Salmonella spp. are among the most dangerous food borne bacterial pathogens in terms of human health and disease (Olsen et al. 2000) [3].

Ready-to-eat foods have been implicated in several outbreaks of listeriosis (CDC,2002) [4]. The largest outbreaks of human listeriosis have involved dairy products (Harvey and Gilmour 1993) [5]. Escherichia coli, particularly serotype 0157:H7 has become an important food borne pathogen responsible for gastroenteritis epidemics in North America, Europe, Asia and Africa and the most frequently implicated foods have been undercooked, contaminated ground beef, raw milk, unpasteurised cider and apple juice, bean sprouts or fresh leafy vegetables such as lettuce and spinach (Altekruse et al. 1997) [6]. Various serotypes of Salmonella spp., including $S$. Enteritidis, have been reportedly responsible for food borne epidemics in various countries (Todd 1997) [7], emphasizing the importance of the pathogen as a food safety concern.

\footnotetext{
*Address correspondence to this author at the School of Veterinary Medicine, Faculty of Medical Sciences, University of the West Indies, St. Augustine, Trinidad and Tobago, West Indies;

E-mail: aadesiyun@gmail.com
}

In Trinidad and Tobago, L. monocytogenes has been isolated from bulk milk $(1.7 \%)$, raw meat $(1.9 \%)$, seafood $(5.8 \%)$ and chicken frankfurters 4/11(36.4\%) (Adesiyun 1993 [8]; Adesiyun et al. 1996 [9]; Adesiyun and Krishnan 1995 [10]; Gibbons et al. 2006 [11]; Adesiyun et al. 2007 [12]), but there is a dearth of information on ready-to-eat foods sold across supermarkets in the country. E. coli O157 has also been isolated from the water supply to rural communities (2.0\%) (Welch et al. 2000) [13], local delicacies such as oysters (2\%) (Rampersad et al. 1999) [14] and 'black pudding' (13.6\%) (Adesiyun and Balbirsingh 1996 [9]) and from pre-processed cows' milk (0.8\%) (Adesiyun et al. 2007) [12]. The first case of neonatal septicaemia and meningitis due to L. monocytogenes was reported in Trinidad in 1998, (Ashiru and Bratt 1998) [15] when symptoms appeared three days after a blood transfusion. Information on the frequency of abortion and neonatal illness due to Listeria spp. in Trinidad is unavailable, as these cases are often treated symptomatically. In Trinidad and Tobago, Salmonella spp. have been recovered from oysters, $2.3 \%$ (Rampersad et al. 1999) [14], black pudding, 8\% (Adesiyun and Balbirsingh 1996) [9] and table eggs, $13.0 \%$ (Adesiyun et al. 2005) [16].

This study was therefore carried out since there is currently no report on a comprehensive assessment of the bacterial health risk posed to consumers of ready-to-eat food products sold across the country.

\section{MATERIALS AND METHODOLOGY}

\subsection{Selection of Supermarkets}

Supermarkets were sampled across the country and grouped based on the number of cash registers present (Meldrum et al. 2006) [17]. Stores with < 3 cash registers were classified as small, 3- 7 as medium and $>7$ as large.

\subsection{Selection of Products to Sample}

Five groups of commonly consumed ready-to-eat foods, namely vegetables, pasteurised milk, cheese, deli meats and seafood from supermarkets were selected (Table 1), based on 
the findings of the questionnaire. Overall, a total of three hundred and fifty three (353) samples of ready-to-eat foods were collected comprising vegetables (71), pasteurised milk (70), deli meats (70), seafood (70) and cheeses (72).

Table 1. Types of Products Sampled for Testing

\begin{tabular}{|c|l|}
\hline Products & \multicolumn{1}{|c|}{ Type } \\
\hline \hline Vegetables & $\begin{array}{l}\text { Lettuce, Cucumber, Cabbage, Sweet-pepper, } \\
\text { Carrots }\end{array}$ \\
\hline Pasteurised milk & $\begin{array}{l}\text { Peanut Punch, Sea-moss, Linseed and Seamoss } \\
\text { and Yogurt Drink, Pasteurised milk. }\end{array}$ \\
\hline Deli meats & $\begin{array}{l}\text { Sliced Bologna, Chicken Bologna, Turkey Breast } \\
\text { Loaf, Chicken Franks, Turkey Pack, Cooked } \\
\text { Ham }\end{array}$ \\
\hline Seafood & $\begin{array}{l}\text { Imitation Crab Meat, Imitation Lobster Meat, } \\
\text { Prawns, Smoked Salmon, Smoked herring, } \\
\text { Shrimp, Crayfish }\end{array}$ \\
\hline Cheese & $\begin{array}{l}\text { Pre-packaged cheddar, supermarket packaged } \\
\text { cheddar }\end{array}$ \\
\hline
\end{tabular}

\subsection{Processing of Samples}

Samples were purchased as regular customers and transported to the laboratory ice-cooled and processed within 24 h. Representative sections of the sample were taken using sterile utensils and placed in sterile plastic containers. Ten grams each of sample were added to $90 \mathrm{mls}$ lactose broth (Oxoid Ltd., Hampshire, England) and 90 mls Listeria Enrichment broth (LEB) (Oxoid Ltd., Hampshire, England) in stomacher bags. The samples were emulsified separately in a Seward 400 Lab Stomacher (London, U.K.) at high speed for 120 seconds.

The lactose broth emulsion was then used to determine the total aerobic plate count (TAPC), by making serial dilutions using sterile saline and surface plating on nutrient agar plates and eosin methylene blue (EMB) agar (Oxoid Ltd., Hampshire, England) in duplicate. Inoculated plates were incubated aerobically at $37^{\circ} \mathrm{C}$ for $48 \mathrm{~h}$ after which the colonies were enumerated using a Quebec Darkfield Colony Counter (Cambridge Instruments Inc., Buffalo, USA). The mean count of colonies on duplicate plates were determined. Subsequently, the lactose broth emulsion was incubated at $37^{\circ} \mathrm{C}$ for $24 \mathrm{~h}$ to enrich for Salmonella spp.

\subsection{Detection of Listeria spp.}

The LEB suspension was incubated at $30^{\circ} \mathrm{C}$ for $24 \mathrm{~h}$ after which one $\mathrm{ml}$ was put into $9 \mathrm{mls}$ of Fraser broth and incubated at $30^{\circ} \mathrm{C}$ for $24 \mathrm{~h}$. A loopful was plated on Listeria selective agar (LSA) as the conventional method. One $\mathrm{ml}$ of the Fraser broth suspension was used for Immunomagnetic separation (Slade 1992) [18] using the Dyna Bead Automated Immunomagnetic Separation (IMS) machine (Thermo Electron Corporation, Finland) to isolate L. monocytogenes. LSA plates were also inoculated with processed samples from IMS and incubated at $37^{\circ} \mathrm{C}$ for $48 \mathrm{~h}$. Characteristic dark-brown or black colonies were then selected and inoculated onto blood agar plates (BAP) which were incubated at $30^{\circ} \mathrm{C}$ for $24 \mathrm{~h}$. Presence of haemolysis was noted and pure cultures were used to inoculate motility medium which was incubated at room temperature for $48 \mathrm{~h}$. Isolates with 'umbrella motility' were subjected to standard biochemical tests (Macfaddin 2000) [19]. Isolates showing reactions characteristic of $L$. monocytogenes were then subjected to the slide agglutination test using specific L. monocytogenes antiserum (Difco Laboratories, Detroit, Michigan, USA).

To detect $L$. monocytogenes using an immunologic method, TECRA, one $\mathrm{ml}$ of inoculated Fraser broth suspension was added to $50 u$ ls sample additive in a tube and heated for fifteen minutes in a boiling water bath. Two hundred $u$ ls of the suspension was then used to inoculate one well of the TECRA test kits per sample (Slade 1992) [18]. The optical density after incubation was determined by spectrophotometry using an ELISA plate reader (Labsystems, Finland) and the results interpreted as recommended by the kit manufacturer.

\subsection{Isolation of $E$. coli}

Incubated lactose broth suspension was plated on eosin methylene blue (EMB) and sorbitol McConkey (sMAC) agar and incubated overnight at $37^{\circ} \mathrm{C}$. Characteristic metallic green colonies from EMB were plated for isolation on blood agar plates (BAP) and incubated at $37^{\circ} \mathrm{C}$ for $24 \mathrm{~h}$, and nonsorbitol fermenting (NSF) and sorbito-fermenting (SF) colonies on sMAC were identified as E. coli using standard methods (Macfaddin 2000) [19]. NSF colonies were screened for the $\mathrm{O} 157$ strain using E. coli $\mathrm{O} 157$ antiserum (Oxoid Ltd., Basingstoke, U.K.) by slide agglutination test.

\subsection{Isolation of Salmonella spp.}

One millilitre each of the lactose broth suspension incubated at $37^{\circ} \mathrm{C}$ for $24 \mathrm{~h}$ was inoculated into $9 \mathrm{mls}$ of selenite cysteine (SC) and $9 \mathrm{mls}$ of tetrathionate (TT) and $200 u$ ls of iodine broth and incubated overnight at $42^{\circ} \mathrm{C}$ and $37^{\circ} \mathrm{C}$ respectively. Growths in SC and TT broths were then inoculated and plated for isolation in bismuth sulphite (BS) and xylose lysine desoxycholate (XLD) agar and incubated at $37^{\circ} \mathrm{C}$ for $24 \mathrm{~h}$. Isolates with characteristic appearance on BS and XLD plates were identified using standard methods (Macfaddin 2000) [19]. Isolates that were biochemically identified as Salmonella spp. were confirmed serologically using the Polyvalent Salmonella (A-E \& Vi) antisera (Benex Ltd., Shannon, Ireland).

\subsection{Statistical Analysis}

Data were analyzed to determine if there was a relationship between food group and presence of $L$. monocytogenes, E. coli, E. coli O157, other coliforms and Salmonella spp. The possible association of supermarket size, food group, the type of food, microbial load of the products and the type of bacteria were also analysed. The Statistical Package for Social Sciences (SPSS) (Version 13) was used to process the data and analysis was by the chi-square test with level of significance set at $\alpha=0.05$.

\section{RESULTS}

Table 2 shows the $\log 10$ mean total aerobic plate count and SD per $\mathrm{g} / \mathrm{ml}$ of the different food groups tested. Vegetables had the highest TAPC, followed by pasteurised milk, 
cheese, deli meats and lowest in seafood. The difference was statistically significant $(\mathrm{p}=0.00)$.

Table 2. Mean Log + SD TAPC for Each Product Group Tested

\begin{tabular}{|c|c|c|}
\hline Product & No. of Samples & $\begin{array}{c}\log \text { Mean } \pm \text { SD TAPC per } \mathrm{g} \\
{\text { or } \mathrm{ml}^{\mathrm{a}}}^{\mathrm{a}}\end{array}$ \\
\hline Vegetables & 71 & $11.0 \pm 11.6$ \\
\hline Pasteurised milk & 70 & $8.6 \pm 9.3$ \\
\hline Cheese & 72 & $7.0 \pm 7.8$ \\
\hline Deli meats & 70 & $6.1 \pm 6.4$ \\
\hline Seafood & 70 & $5.2 \pm 5.7$ \\
\hline Total & 353 & $10.4 \pm 11.3$ \\
\hline
\end{tabular}

${ }^{a} \log _{10}$ mean of 212 samples.

Forty-one (58.6\%) of seventy (70) deli meat samples and forty $(57.1 \%)$ of seventy (70) seafood samples had TAPC counts $<10^{2} \mathrm{cfu}$ per $\mathrm{g}$ of sample, which was within acceptable levels. Samples from large supermarkets had significantly higher TAPCs, followed by those from medium supermarkets and least contaminated from small supermarkets $(\mathrm{p}=0.00)$.
The frequency of detection of the pathogens in the food products is shown in Table 3. Pasteurised milk and milk products had the highest prevalence of $E$. coli, coliforms and L. monocytogenes. The difference in prevalence across food products was statistically significant $(\mathrm{p}=0.00)$. Coliforms were detected at a significantly higher frequency in pasteurised milk and vegetables $(\mathrm{p}=0.00), E$. coli was detected in significantly higher frequency in pasteurised milk and milk products than in the other groups $(p=0.004)$. No relationship was detected between groups of foods and frequency of detection of Listeria monocytogenes ( $\mathrm{P}>0.05)$.

L. monocytogenes was isolated from pasteurised milk, as well as from a beverage containing pasteurised milk, linseed, pumpkin and carrot. It was also isolated from lettuce, cooked shrimp and smoked herring. The characteristics of the E. coli isolates are shown in Table 4 . None of the $E$. coli isolates was an 0157 serotype.

Table 5 shows the number of samples positive for $L$. monocytogenes by the three methods used for detection. Forty-nine (13.9\%) of the three hundred and fifty three (353) samples tested positive for L. monocytogenes using a combination of the three assay methods but L. monocytogenes was only isolated from six $(1.7 \%)$ samples.

\section{DISCUSSION}

The prevalence of L. monocytogenes in RTE products found in this study $(1.7 \%)$ is lower than that found in Bel-

Table 3. Frequency of Isolation of the Microorganisms from the Product Groups Tested

\begin{tabular}{|c|c|c|c|c|c|}
\hline \multirow{2}{*}{ Product } & \multirow{2}{*}{ No. of samples tested } & \multicolumn{4}{|c|}{ No. $(\%)$ positive for: } \\
\hline & & \multicolumn{2}{|c|}{ Coliforms } & Listeria monocytogenes & Salmonella spp. \\
\hline Vegetables & 71 & $1(1.4)$ & $12(16.9)$ & $1(1.4)$ & $0(0.0)$ \\
\hline Deli meats & 70 & $2(2.9)$ & $4(5.7)$ & $1(1.4)$ & $0(0.0)$ \\
\hline Cheese & 72 & $2(2.9)$ & $6(8.3)$ & $0(0.0)$ & $0(0.0)$ \\
\hline Seafood & 70 & $2(2.9)$ & $3(4.3)$ & $2(2.9)$ & $0(0.0)$ \\
\hline Total & 353 & $16(4.5)$ & 45 (12.7) & $6(1.7)$ & $0(0.0)$ \\
\hline
\end{tabular}

Table 4. Characteristics of $E$. coli Isolated in the Study

\begin{tabular}{|c|c|c|c|c|c|}
\hline \multirow{2}{*}{ Product } & \multirow{2}{*}{ No. E. coli isolated } & \multicolumn{3}{|c|}{ No. (\%) of E. coli that were: } \\
\cline { 3 - 6 } & & Haemolytic & Mucoid & NSF & $1(100.0)$ \\
\hline \hline Vegetables & 1 & $0(0.0)$ & $1(100.0)$ & $0(0.0)$ \\
\hline Pasteurised Milk & 9 & $4(50.0)$ & $9(100.0)$ & $1(12.5)$ & $0(0.0)$ \\
\hline Deli meats & 2 & $2(100.0)$ & $2(100.0)$ & $1(100.0)$ & $1(50.0)$ \\
\hline Seafood & 2 & $0(0.0)$ & $2(100.0)$ & $2(0.0)$ & $0(100.0)$ \\
\hline Cheese & 2 & $2(100.0)$ & $2(100.0)$ & $0(0.0)$ \\
\hline Total & $\mathbf{1 6}$ & $\mathbf{8 ( 5 0 . 0 )}$ & $\mathbf{1 6}(\mathbf{1 0 0 . 0})$ & $\mathbf{6 ( 4 0 . 0 )}$ & $\mathbf{0}(\mathbf{0 . 0})$ \\
\hline
\end{tabular}


Table 5. Comparing the Methods of Detection Used for L. monocytogenes

\begin{tabular}{|c|c|c|}
\hline Isolation procedure & No. of samples tested & No. (\%) positive for L. monocytogenes \\
\hline \hline Conventional & 353 & $3(0.9)$ \\
\hline IMS & 353 & $4(1.1)$ \\
\hline TECRA & 353 & $42(11.9)$ \\
\hline TECRA + IMS & 353 & $0(0.0)$ \\
\hline TECRA + Conventional & 353 & $1(0.3)$ \\
\hline Conventional + IMS & 353 & $1(0.3)$ \\
\hline
\end{tabular}

gium (23.4\%) (Van Coillie et al. 2004) [20], Japan (3.3\%) (Inoue et al. 2000) [21] and Italy (12.8\%) (Gianfranceschi et al. 2004) [22]. In a study conducted on a variety of ready to eat foods namely pate, salad vegetables, smoked salmon, prepared salads and cooked/cured meats in Northern Ireland (Harvey and Gilmour 1993) [5], L. monocytogenes was isolated from salad vegetables (7/85) and smoked salmon (1/16). A higher prevalence of L. monocytogenes was found by (Harvey and Gilmour 1993) [5] in vegetables compared to our study where only one vegetable sample yielded a $L$. monocytogenes isolate.

Of all the vegetables tested in the current study, only one lettuce sample was positive for L. monocytogenes. In a study performed by (Heisick et al. 1989) [23] in Minnesota, L. monocytogenes was isolated from cabbage, cucumbers, potatoes, and radishes but only L. innocua was isolated from lettuce.

Failure to isolate Salmonella spp. in ready-to-eat foods in the current study is similar to findings reported elsewhere in Wales (Meldrum et al. 2006) [17] and Nigeria (Umoh and Odoba 1999) [24] but at variance with the prevalence of $17 \%$ reported in Malaysia (Arumugaswamy et al. 1995) [25].

The high prevalence of coliforms in RTE foods could be due to, amongst other factors, contaminated water used to clean equipment and cutting/slicing machines leading to cross-contamination especially if used with raw foods, handlers not practising proper sanitation and faulty pasteurisation equipment and monitoring devices. In Europe, it has been reported that $25 \%$ of food borne outbreaks could be traced back to recontamination (WHO 1995) [26].

The isolation of coliforms from vegetables was not unexpected since water used to irrigate vegetable crops and the manure used as fertiliser are reported to contain coliforms and other enteric bacteria (Gagliardi and Karns 2000) [27]. The high prevalence and counts of coliforms found in the vegetables studied may, also be explained by the fact that the vegetable samples were not washed before processing. This was because the study was aimed at determining the risk associated with consuming these products as purchased, bearing in mind that sanitary practices post-purchase and prior to consumption may vary across households in the country, in that a number of individuals consume these products as purchased.

Vegetables tested in the current study were found to have the highest log mean TAPC $(11.0 \pm 11.6 \mathrm{CFU}$ per g) in com- parison to the other food groups tested. A study done by (Albrecht et al. 1995) [28] reported the log mean TAPC of vegetables in Nebraska to range from 5.51 to $6.63 \mathrm{log}$ CFU/g. In Taiwan the log mean TAPC of vegetables ranged from $3.30-8.64 \log \mathrm{CFU} / \mathrm{g}$ with similar counts in meat and seafood. Seafoods sampled in the current study were found to have a lower TAPC in comparison to the other food groups tested, however counts obtained $(5.2+5.7)$ were within the range of the counts found in the study in Taiwan (Fang et al. 2003) [29]. Average aerobic plate counts for salad vegetables in India were greater than $10^{10} \mathrm{cfu} / \mathrm{g}$ (Viswanathan and Kaur 2001) [30]. In the Republic of Cyprus, high $\left(>10^{4} \mathrm{CFU} / \mathrm{g}\right)$ TAPC's were found in $23.5 \%$ of ready to eat foods (Eleftheriadou et al. 2002) [31].

The process of pasteurisation is aimed at killing all of the pathogenic organisms in milk, and also to reduce the natural microbial flora of milk (Altekruse et al. 1998) [32]. Outbreaks of disease in humans have been traced both to the consumption of unpasteurised and pasteurised milk. Milk borne pathogens may enter via contaminated raw milk into dairy food processing plants and these pathogens may persist in bio-films, subsequently contaminating processed milk products and leading to the exposure of consumers to pathogenic bacteria. Furthermore, pathogens such as L. monocytogenes have been reported to be capable of surviving and thriving in post-pasteurisation processing environments thus leading to recontamination of dairy products (Harvey and Gilmour 1993) [5]. These pathways pose a risk to the consumer from direct exposure to food borne pathogens present in un-pasteurised dairy products as well as dairy products that become re-contaminated after pasteurisation (Oliver et al. 2005) [33].

In this study, pasteurised milk was found to be most contaminated with coliforms. The frequency of detection of coliforms, as well as L. monocytogenes and E. coli indicates a faulty pasteurisation process, post-pasteurisation contamination, or improper storage post-pasteurisation. Listeria spp. has also been detected in pasteurised milk in Brazil $(0.9 \%)$ (Moura et al. 1993) [34], England and Wales (1.1\%) (Greenwood et al. 1991) [35] and Egypt (4\%) (Ahmed and Hussein 2005) [36].

Coliforms have been detected in pasteurised milk worldwide, including Australia (Jensen et al. 2001) [37], Bulgaria (Kaloianov and Gogov 1977) [38], Brazil (Da Silva et al. 2001) [39], and Scandinavia (Persson et al. 1980) [40], all findings which concur with the current study. 
The public health significance of detecting pathogens in the samples of pasteurised milk and other milk products studied cannot be ignored. This is because it has been estimated that of diseases due to milk and milk products among food-borne diseases recorded in France and in other countries since 1980, a total of 17,405 cases of disease due to $L$. monocytogenes, Salmonella spp., E. coli or S. aureus were linked to pasteurised milk with 22 deaths (De Buyser et al. 2001) [41]. Outbreaks of listeriosis linked to pasteurised milk have been reported in Massachusetts (Fleming et al. 1985) [42] and Illinois (Dalton et al. 1997) [43]. Pasteurised milk has also been linked to outbreaks of disease due to $E$. coli in North Cumbria (Goh et al. 2002) [44]. TECRA was found to be highly sensitive but not specific in comparison to IMS and conventional methods. This finding was expected because TECRA is an immunological assay which requires the presence of the microorganism as an antigen, dead or alive. Other studies comparing the sensitivity and specificity of ELISA to bacteriological methods have however reported a good correlation between the two methods. Using a different ELISA (Utyyendaele et al. 1995) [45] obtained no false positives or negatives while the Modified FDA method yielded some false-negatives. Other research by (Noah et al. 1991) [46] compared TECRA with another ELISA ListeriaTek and a bacteriological analytical manual (BAM) method and reported that TECRA was the most sensitive test detecting 40 confirmed samples as having $L$. monocytogenes while Listeria -Tek detected 37 positives and the BAM detected 38 of a total of 178 samples. Differences in results of the ELISAs compared with those of the BAM method were not statistically significant, however, differences between results of the two ELISAs were significant.

E. coli $\mathrm{O} 157$ was not isolated from any of the samples in the current study, a finding similar to the reports of (Mankee et al. 2005) [47] on 'doubles' in Trinidad. The organism has however been isolated from bulk milk in Trinidad where three $(0.8 \%)$ out of three-hundred and eighty-six (386) samples were positive for E. coli $\mathrm{O} 157$ (Adesiyun et al. 2007) [48].

It was concluded that the high microbial load, coupled with the isolation of Listeria monocytogenes, Salmonella spp. and E. coli in popular RTE foods in Trinidad could pose a health risk to consumers.

\section{ACKNOWLEDGEMENTS}

The authors wish to thank the staff of the Veterinary Public Health Department, the Veterinary Diagnostic Laboratory, the St. Augustine Campus Research Fund Committee for funding the project and of course our family and friends.

\section{REFERENCES}

[1] Huss HH, Jørgensen LV and Vogel BF. Control options for Listeria monocytogenes in seafoods. Int J Food Microbiol 2000; 62(3): 267274.

[2] Rosmini MR, Signorini ML, Schneider R. Bonazza JC. Evaluation of two alternative techniques for counting mesophilic aerobic bacteria in raw milk. Food Control 2004; 15(1): 39-44.

[3] Olsen SJ, MacKinnon LC, Goulding JS, Bean NH, Slutsker L. MMWR CDC Surveill. Summ 2000; 49: 1.

[4] Public Health Dispatch: Outbreak of Listeriosis --- Northeastern United States, 2002 Centers for Disease Control and Prevention, Atlanta, Georgia, USA. MMWR weekly 2002; 51 (42): 950-951.
[5] Harvey J, Gilmour A. Occurrence of Listeria species in raw milk and dairy products in Northern Ireland. J Appl Bacteriol 1992; 72: 119-125.

[6] Altekruse SF, Cohen ML, Swerdlow DL. Emerging foodborne diseases. Emerg Infect Dis1997; 3: 3.

[7] Todd EC. Epidemiology of foodborne diseases: a worldwide review. World Health Statistics Quarterly. 1997; 50(1-2): 30-50.

[8] Adesiyun AA. Prevalence of Listeria spp., Campylobacter spp. Salmonella spp. Yersinia spp. and toxigenic Escherichia coli meat and seafoods in Trinidad. Food Microbiol 1993; 10: 395-403.

[9] Adesiyun AA, Balbirsingh V. Microbiological analysis of 'black pudding', a Trinidadian delicacy and health risk to consumers. Int J Food Microbiol1996; 31: 283-299.

[10] Adesiyun AA, Krishnan, C. Occurrence of Yersinia enterocolitica O: 3, Listeria monocytogenes O: 4 and thermophilic Campylobacter spp. in slaughter pigs and carcasses in Trinidad. Food Microbiol 1995; 12: 99-107.

[11] Gibbons I, Adesiyun AA, Seepersadsingh N, Rahaman S. Investigation for possible source(s) of contamination of ready-to-eat meat products with Listeria spp. and other pathogens in a meat processing plant in Trinidad. Food Microbiol 2006; 23(4): 359-366.

[12] Adesiyun AA, Stoute S, David B. Pre-processed bovine milk quality in Trinidad: Prevalence and characteristics of bacterial pathogens and occurrence of antimicrobial residues in milk from collection centres. Food Control 2007; 18(4): 312-320.

[13] Welch P, David J, Clarke W, et al. Microbial quality of water in rural communities of Trinidad. Revista Panamericana de Salud Publica 2000; 8: 3 .

[14] Rampersad FS, Laloo S, La Borde A, et al. Microbial quality of oysters sold in Western Trinidad and potential health risk to consumers. Epidemiol Infect 1999; 123: 241-250.

[15] Ashiru JO, Bratt D. Listeria septicaemia and meningitis in a neonate: case report. East Afr Med J 1998; 75(4): 249-51.

[16] Adesiyun AA, Offiah N, Seepersadsingh N, et al. Microbial health risk posed by table eggs in Trinidad. Epidemiol Infect 2005; 133 : 1049-1056.

[17] Meldrum J, Smith RMM, Ellis P, Garside J. Microbiological quality of randomly selected ready-to-eat foods sampled between 2003 and 2005 in Wales, UK. Int J Food Microbiol 2006; 108(3): 1397 400 .

[18] Slade PJ. Monitoring Listeria in the food production environment. II. Identification techniques. Food Res Int 1992; 25(1): 45-56.

[19] MacFaddin JF. Biochemical Tests for Identification of Medical Bacteria, Lippincott Williams \& Wilkins, Philadelphia, USA 2000.

[20] Van Coillie E, Werbrouck H, Heyndrickx M, Herman L, Rijpens L. Prevalence and Typing of Listeria monocytogenes in Ready-to-Eat Food Products on the Belgian Market. J Food Protect 2004; 67(11): 2480-2487.

[21] Inoue S, Nakama A, Arai Y, et al. Prevalence and contamination levels of Listeria monocytogenes in retail foods in Japan. Int J Food Microbiol 2000; 25; 59(1-2): 73-7.

[22] Gianfranceschi M, Gattuso A, Tartaro S, Aureli P. Incidence of Listeria monocytogenes in food and environmental samples in Italy between 1990 and 1999: Serotype distribution in food, environmental and clinical samples. Eur J Epidemiol 2003; 18: 10.

[23] Heisick JE, Wagner DE, Nierman ML, Peeler JT. Listeria spp. found on fresh market produce. Appl Environ Microbiol 1989; 55(8): 1925-1927.

[24] Umoh VJ, Odobab MB. Safety and quality evaluation of street foods sold in Zaria, Nigeria. Food Control 1999; 10: 9-14.

[25] Arumugaswamy RK, Rusul G, Abdul Hamid SN, Cheah CT. Prevalence of Salmonella in raw and cooked foods in Malaysia. Food Microbiol 1995; 12(1): 3-8.

[26] WHO (World Health Organisation). Surveillance Programme. Sixth Report of WHO Surveillance Programme for Control of Foodborne Infections and Intoxications in Europe. FAO/WHO Collaborating Centre for Research and Training in Food Hygiene and Zoonoses, Berlin 1995.

[27] Gagliardi JV, Karns JS, Leaching of Escherichia coli O157: H7 in Diverse Soils under Various Agricultural Management Practices. Appl Environ Microbiol 2000; 6(3): 877-883.

[28] Albrecht JA, Hamouz FL; Sumner SS, Melch, V. Microbial Evaluation of Vegetable Ingredients in Salad Bars. J Food Protect 1995; 58(6): 683-685(3). 
[29] Fang TJ, Wei QK, Liao CW, Hung MJ, Wang TH. () Microbiological quality of $18{ }^{\circ} \mathrm{C}$ ready-to-eat food products sold in Taiwan. Int J Food Microbiol 2003; 15: 241-250.

[30] Viswanathan P, Kaur R. Prevalence and growth of pathogens on salad vegetables, fruits and sprouts. Int J Hygiene Environ Health 2001; 203(3): 205-213.

[31] Eleftheriadou M, Varnava-Tello A, Metta-Loizidou M, Nikolaou A, Akkelidou D. The microbiological profile of foods in the Republic of Cyprus: 1991-2000. Food Microbiol 2002; 19(5): 463471.

[32] Altekruse SF, Timbo BB, Mowbray JC, Bean NH, Potter ME. Cheese-associated outbreaks of human illness in the United States, 1973 to 1992: Sanitary manufacturing practices protect consumers. J Food Protect 1998; 61(10): 1405-1407.

[33] Oliver SP, Jayarao BM, Almeida RA. Foodborne pathogens in milk and the dairy farm environment: food safety and public health implications. Foodborne Pathog Dis 2005; 2(2): 115-29.

[34] Moura SM, Destro MT, Franco BDGM. Incidence of Listeria species in raw and pasteurized milk produced in Sao Paulo, Brazil. Int J Food Microbiol 1993; 19: 229-237.

[35] Greenwood MH, Roberts D, Burden P. The occurrence of Listeria species in milk and dairy products: a national survey in England and Wales. Int J Food Microbiol 1991; 12(2-3): 197-206.

[36] Ahmed EK, Hussein SZ. Incidence of Listeria monocytogenes in pasteurized milk and some pasteurized milk products and effect of boiling on its viability. Assiut Vet Med J 2005; 105(51) 89-99.

[37] Jensen N, Varelis P, Whitfield FB. Formation of guaiacol in chocolate milk by the psychrotrophic bacterium Rahnella aquatilis. Lett Appl Microbiol 2001; 33(5): 339-343

[38] Kaloianov I, Gogov I. Coliform bacteria in raw and pasteurised milk. Vet Med Nauki 1977; 14(10): 46-52.

[39] Da Silva ZN, Da Cunha AS, Lins MC, et al. Isolation and serological identification of enteropathogenic Escherichia coli in pasteur- ised milk in Brazil. Revista de Saude Publica, Sao Paulo Rev. Saude Publica, Sao Paulo 2001 35(4): 375-379.

[40] Persson L, Olsson B, Franklin A. Antibiotic resistance patterns of coliform bacteria isolated from food. Scand J Infect Dis 1980 12(4): 289-94.

[41] De Buyser ML, Dufour B, Maire M, Lafarge V. Implication of milk and milk products in food-borne diseases in France and in different industrialised countries. International J Food Microbiol 2001; 67(1-2): 1-17.

[42] Fleming DW, Cochi SL, MacDonald KL, et al. Pasteurised milk as a vehicle of infection in an outbreak of listeriosis. New Engl J Med 1985; 312: 404-407.

[43] Dalton CB, Austin CC, Sobel J, et al. An outbreak of gastroenteritis and fever due to Listeria monocytogenes in milk. New Engl J Med 1997; 336(2): 100-105.

[44] Goh S, Newman C, Knowles M, et al. E. coli O157 phage type 21/28 outbreak in North Cumbria associated with pasteurised milk. Epidemiol Infect 2002; 129: 451-457.

[45] Uyttendaele M, Schukkink R, Van Gemen B, Debevere J. Development of NASBA, a nucleic acid amplification system, for identification of Listeria monocytogenes and comparison to ELISA and a modified FDA method. Int J Food Microbiol 1995; 27(1): 77-89.

[46] Noah CW, Ramos NC, Gipson MV. Efficiency of two commercial ELISA kits compared with the BAM culture method for detecting Listeria in naturally contaminated foods. J Assoc Off Anal Chem 1991; 74(5): 819-21.

[47] Mankee A, Ali S, Chin A, et al. Microbial quality of "doubles" sold in Trinidad. Food Microbiol 2005; 22(6): 601-607.

[48] Adesiyun AA, Webb LA, Romain H, Kaminjolo S. Prevalence of Salmonella, Listeria monocytogenes, Campylobacter spp., Yersinia enterocolitica and Cryptosporidium spp. in bulk milk, cows' faeces and effluents of dairy farms in Trinidad. Revue d'Elevage et de Medecine Veterinaire des Pays Tropicaux 1996; 49(4): 303-9. 